Tomasz CZUBARA

Wyższa Szkoła Administracji, Szczecin

\title{
Proces konstytucyjny na Ukrainie w latach 1990-2006
}

iniejsza praca jest próbą opisu procesu konstytucyjnego na Ukrainie
w latach 1990-2006 w kontekście sporów toczacych sie na linii Prezydent-Rada Najwyższa Ukrainy. Konstytucja ukraińska determinuje system polityczny i administracyjny kraju. Proponowane zmiany do niej, w zależności od sytuacji politycznej w kraju faworyzowały bądź to Prezydenta, bądź Radę Najwyższą. Pomimo wielu prób, na Ukrainie wciąż nie zrealizowano najważniejszych reform systemowych, co nie sprzyja stabilizacji kraju. Tworzenie podstaw systemu ustrojowego niezależnego państwa ukraińskiego jest dobrym przykładem tego, jak partykularne interesy poszczególnych sił politycznych wpływają negatywnie na kształtowanie się społeczeństwa obywatelskiego i opartego na przejrzystych zasadach samorządu lokalnego. Aktualna sytuacja, kiedy w proces reform zaangażowały się wszystkie siły polityczne, a także eksperci zagraniczni, między innymi z Polski, pozwala mieć nadzieję, że wkrótce sytuacja w tym obszarze zostanie ustabilizowana.

\section{Droga do nowej Konstytucji Ukrainy}

Zmiany, jakie nastapiły w postradzieckich republikach po rozpadzie ZSRR wymagały stworzenia nowych politycznych, społecznych i ekonomicznych umów, jakie przystawałyby do nowych czasów. Proces reformowania wymienionych sfer funkcjonowania społeczeństwa ukraińskiego znalazł odzwierciedlenie w ewolucji konstytucyjnych zasad Ukrainy.

Transformacja elit i czas przejścia państwa z systemu autorytarnego do demokratycznego różni się w zależności od kraju przechodzącego transformację. Specyfiką Ukrainy był prymitywny przewrót polityczny, który spowodował skłócenie elit ${ }^{1}$.

A. I. Kudriaczenko (red.), Politiczna sistema i gromadianskie suspilstwo: Ewropejski i Ukrajinski realii (System polityczny i społeczeństwo obywatelskie: Europejskie i Ukraińskie realia), Kijiw 2007, s. 123. 
16 lipca 1990 roku Rada Najwyższa (Wierchowna Rada) URSR ${ }^{2}$ przyjęła Deklarację państwowej suwerenności Ukrainy ${ }^{3}$. W dokumencie tym określono nie tylko podstawy organizacji władzy na Ukrainie i ustrój ekonomiczno-społeczny, ale zaznaczono także, że Deklaracja jest ,podstawą dla nowej Konstytucji i ustaw Ukrainy oraz wyznacza pozycje Republiki przy tworzeniu międzynarodowych porozumień" ${ }^{4}$. Deklaracja akcentowała także konieczność odbudowy Ukrainy, jako suwerennego, narodowego, praworządnego i demokratycznego Państwa.

Jeszcze przed uchwaleniem Deklaracji, Rada Najwyższa przyjęła „Ustawę o zmianach i uzupełnieniu Konstytucji USRR”. Wzmacniała ona pozycję Przewodniczącego Rady posiadającego od tej pory status najwyższego urzędnika w państwie i zmniejszyła liczbę deputowanych do 450 osób. Ustawa umożliwiła także przeprowadzenie w 1990 r. częściowo wolnych wyborów do Rady Najwyższej ${ }^{5}$.

Kiedy w sierpniu 1991 roku w Moskwie nastapił przewrót państwowy, ukraińscy komunistyczni liderzy obrali drogę do niezależności w celu utrzymania się przy władzy. To z kolei determinowało nadzwyczajnie powolny postęp politycznych i ekonomicznych reform. Kierownicy przedsiębiorstw WPK ${ }^{6}$, rozmieszczonych przeważnie we Wschodniej Ukrainie,

2 Ros. Украинская Советская Сочиалистическая Республика, Украинская CCP - czyt.: Ukrainskaja Sowietskaja Socialisticzeskaja Riespublika, ukr. Укpaїнська Радянська Сочіалістична Республіка, Українська PCP - czyt.: Ukrajins 'ka Radians 'ka Socjalistyczna Republika, pol. Ukraińska Socjalistyczna Republika Radziecka, Ukraińska Socjalistyczna Republika Sowiecka.

3 Deklaracija pro dierżawnyj suwernitet Ukrajiny - Wierchowa Rada URSR: Deklaracija z 16.07.1990, nr 55-XII. (oryg. Декларація про державний суверенітет України - Верховна Рада УРСР; Декларація від 16.07.1990, № 55-XII), Widomosti Wierchownoji Radi (WWR), 1990, nr 31, s. 429.

4 Ibidem, s. 429.

5 Zakon URSR pro zminy ta dopownennja Konstytucji URSR z 27.10.1989 r.: WWR nr 45, 1989, s. 624, za: W. Baluk, System polityczny, w: Europa Wschodnia - dekada transformacji-Ukraina, red. B. J. Albin, W. Baluk, Wrocław 2002, s. 5.

6 ВПК (Kompleks Wojskowo-Przemysłowy. Słowo często spotykane we współczesnych leksykonach, nie potrzebujące szczególnych objaśnień. Tym ciekawsze jest, że radzieckie encyklopedie traktowały to pojęcie jako specyficzne związki monopoli, wytwarzające produkty dla armii, a także dla państwowej administracji i aparatu ideologicznego. Przy czym zaznaczano, że takie zjawisko charakterystyczne jest dla krajów kapitalistycznych, szczególnie dla USA. Występowanie WPK w Związku Radzieckim encyklopedie wstydliwie zatajały. I to pomimo, że w ZSRR istniała tak zwana ,„дев'ятка” - „dziewiątka” (dokładnie taka ilość ministerstw bezpośrednio „opiekowała się” obronnością) z tysiącem podporządkowanych jej nauko- 
optowali za odnowieniem ekonomicznych związków z Rosją. Nacjonalistyczne siły polityczne występowały za niezależnością od Rosji, ale sprzeciwiały się programowi prywatyzacji zgodnej z ekonomiką rynkową ${ }^{7}$. Pomimo różnic w postrzeganiu ustroju Państwa, obydwa obozy uznawały konieczność legitymizacji uzyskania niepodległości na poziomie Ustawy Zasadniczej. W ten sposób rozpoczął się proces przygotowania nowej Konstytucji Ukrainy.

Historia konstytucyjna Ukrainy sięga 5 kwietnia 1710 roku, kiedy to uchwalono pierwszą ukraińską Ustawę Zasadniczą, nazywaną Konstytucją Praw i Wolności Wojska Zaporoskiego. Konstytucja przewidywała podział władz na ustawodawczą (Rada Generalna), wykonawczą (Hetman) i sądowniczą (Sąd Generalny). Radę Generalną tworzyła kozacka hierarchia uzupełniana przez posłów pułków i kozactwa zaporoskiego (niżowego) $)^{8}$ W Encyklopedii Ukrainoznastwa opisano kolejne Ustawy Zasadnicze, m.in. Ustawę o tymczasowym państwowym ustroju Ukrainy (Ukraińskiej Republiki Ludowej) z 29 kwietnia 1918 r., Małą Konstytucję przyjętą 28 stycznia 1919 roku przez Pracowniczy Kongres Narodów Ukrainy, Konstytucję z 1937 roku oraz Konstytucję URSR z 1978 roku9 .

Walenty Baluk podaje za W. Pohoriłko, trzy okresy stanowienia nowej Ustawy Zasadniczej: 1) lata 1990-1993; 2) 1994-1995; 3) 1995-1996. ${ }^{10}$ Wydaje się, że należałoby rozszerzyć ten okres na dalsze lata, aż do 2006 roku, gdy zostały wprowadzone ostatnie, jak do tej pory, zmiany do Konstytucji.

24 października 1990 roku Rada Najwyższa zatwierdziła skład pierwszej Konstytucyjnej Komisji (59 członków) jako organu parlamentu, na

wo-doświadczalnych instytutów, instytucji usługowych, w których pracowały miliony obywateli radzieckich. Wszelka informacja odnośnie działalności tej gałęzi była ściśle tajna, dlatego nic dziwnego, że przeważnie specyfikę jej funkcjonowania chętniej ujawniały służby specjalne innych państw niż ci, którzy brali bezpośrednio udział w tworzeniu „obronnego życia ojczyzny”. Kompleksy W-P wciąż funkcjonują na Ukrainie pod nazwą OPK (оборонно-промислового комплекс, obronno-przemysłowy kompleks), w jego skład wchodzi ok. 200 instytucji, w których pracuje blisko 300 tys. osób). Na podstawie wywiadu z pierwszym zastępcą Ministra Polityki Przemysłowej Ukrainy - Olegiem Uruskim zamieszczonym w gazecie „КАМУФЛЯЖ” (Kamuflaż) 2006, № 5 .

7 A. I. Kudriaczenko (red.), op. cit., s. 123.

8 N. Jakowenko, Historia Ukrainy do końca XVIII wieku, Lublin 2000, s. 280.

9 Encyklopedia Ukrainoznawstwa, pod red. W. Kubijowicza, t. 1, Kijiw 1993, s. 360; ibidem, t. 7, Lwiw 1998, s. 2432; ibidem, t. 8, Lwiw 2000, s. 2849.

10 W. Baluk, System polityczny, op. cit., s. 5. 
czele z Przewodniczącym Rady Najwyższej URSR L. Krawczykiem, a już 19 czerwca 1991 r. uchwaliła Koncepcję nowej Konstytucji Ukrainy ${ }^{11}$.

24 sierpnia 1991 r. Rada Najwyższa realizując założenia Deklaracji suwerenności państwowej, przegłosowała niezależność Ukrainy. Akt niezależności oznajmiał, że na terytorium Ukrainy obowiązuje wyłącznie Konstytucja i prawa (ustawy) Ukrainy. Ustawa „O prawo-następstwie Ukrainy” (Про правонаступництво України), uchwalona 12 września 1991 r., do czasu przyjęcia nowej Konstytucji wyznaczała jako obowiązującą Ustawę Podstawową (Основного Закону) USRS, zmieniła nazwę Rady Najwyższej URSR na Radę Najwyższą Ukrainy (wcześniej została zmieniona nazwa władzy wykonawczej Rady Ministrów na Gabinet Ministrów USRR ${ }^{12}$ oraz pojawiła się funkcja Prezydenta, jako „najwyższego urzędnika państwowego oraz zwierzchnika organów zarządzających państwem"13), ustanawiała granice oraz nadawała prawa obywatelskie wszystkim ludziom, którzy zamieszkiwali terytorium Ukrainy w dniu 24 sierpnia $1991 \mathrm{r}^{14}$

1 grudnia 1991 roku w ogólno-ukraińskim referendum 90,32\% biorących w nim udział obywateli, co stanowiło 76\% ogółu obywateli posiadających prawo wyborcze, potwierdziło Akt ogłoszenia niepodległości Ukrainy $^{15}$. Już wtedy uzyskane wyniki w poszczególnych rejonach kraju, ujawniły głęboki podział w społeczeństwie ukraińskim, a co się z tym wiąże głęboki podział polityczny w kluczowych dla Państwa sprawach ${ }^{16}$.

11 A. I. Kudriaczenko, op. cit., s. 123.

12 Zakon pro zminu i dopownennia do Konstytucji (Osnownoho Zakonu) Ukrajinskoji RSR z 21.05.1991 r., WWR, nr 26, 1991, s. 194; za: W. Baluk, System polityczny, op. cit., s. 5 .

13 Zakon pro zminu i dopownennia do Konstytucji (Osnownoho Zakonu) Ukrajinskoji RSR z 5.07.1991 r., WWR, nr 33, 1991, s. 445 (Ustawa o powołaniu instytucji prezydenta z wniesieniem odpowiednich poprawek do Konstytucji USRR; za: W. Baluk, System polityczny, op. cit., s. 5.

${ }_{14}$ Pro prawonastupnictwo Ukrajiny (oryg. Про правонаступництво Украӥни): Zakon Ukrajiny wid 12.09.1991 Nr 1543-XII, WWR, 1991, Nr 46, s. 617.

15 W. Łytwyn, Polityczna arena Ukrainy. Dijowi osoby ta wykonawci, Kijiw 1994, s. 280.

${ }^{16}$ W czterech oblastach - Charkowskim, Ługańskim, Donieckim i Odeskim, gdzie żyje ponad $25 \%$ mieszkańców Ukrainy, Akt Niezależności poparty został przez mniej niż 2/3 mających prawo głosu (62,5\%), a na Krymie - tylko przez ponad 1/3 (35,5\%). Za: W. M. Łytwyn, Ukraina na meżi tisjaczolit, t. 14 (lata 1991-2000), Kijiw 2000, s. 68 . 
W latach 1990-1993 aż 19-krotnie wnoszono różnego rodzaju poprawki do Ustawy Zasadniczej ${ }^{17}$. Konkretne zadania konstytucyjnej reformy na Ukrainie były zdeterminowane czynnikami zarówno wewnętrznymi, jak i zewnętrznymi. Zarówno kryzys finansowo-ekonomiczny w latach 1992-1994, jak i kryzys polityczny z 1994 roku oraz złożoność stosunków z niektórymi krajami sąsiednimi postawiły na porządku dziennym konieczność stworzenia silnego państwa, jako gwaranta narodowej niezależności oraz społeczno-ekonomicznych i politycznych zmian w interesie narodu Ukrainy. Legitymizacją takiego państwa była przygotowywana przyszła Konstytucja ${ }^{18}$.

Odnowienie konstytucyjnego procesu na Ukrainie rozpoczęło się 10 listopada 1994 r., kiedy nowo powołana Rada Najwyższa uchwaliła dekret „O składzie komisji do opracowania nowej Konstytucji Ukrainy”. Status nowej komisji Konstytucyjnej w porównaniu z poprzednią był zmieniony z „komisji Rady Najwyższej” na „tymczasową ogólnopaństwową komisję". Na czele 41-osobowej Komisji stali Prezydent Ukrainy Leonid Kuczma i Przewodniczący Rady Najwyższej O. Moroz ${ }^{19}$.

Trzeba zaznaczyć, że proces tworzenia projektu nowej Konstytucji odbywał się w warunkach szorstkich stosunków Rady Najwyższej i Prezydenta Ukrainy (zgodnie z nowelizacją 14.02.1992 r. „Ustawy o powołaniu instytucji Prezydenta z wniesieniem odpowiednich poprawek do Konstytucji USRR" Prezydent sprawował funkcję głowy państwa i władzy wykonawczej $^{20}$ ) wynikających z konstytucyjnego zakresu pełnomocnictw każdej z tych instytucji władzy w państwowo-politycznym systemie Ukrainy. Proces ten miał konfliktowy charakter i znacznie odbijały się na nim polityczne przeciwieństwa między oboma obozami władzy ${ }^{21}$. W takich warunkach powstał pomysł przyjęcia na okres przejściowy projektu ustawy w formie Małej Konstytucji (na wzór Polskiej Małej Konstytucji z 1992 roku). Leonid Kuczma wniósł do rozpatrzenia przez Radę Naj-

17 W. Baluk, System polityczny, op. cit., s. 6.

18 Konstutycijna reforma w Ukrajini: perebig, stan i percpektiwi: Analit. dop. Centru O. Razumkowa, „Nacjonalna bezpieka i oborona” 2007, nr 1, s. 3.

19 Pro sklad komisiji z opracjuwannja nowoji Konstutyciji Ukrajiny: Postanowi Werchownoji Radi Ukrajiny wid 10.11.1994, nr 231/94-B. WWR, 1994, Nr 46, s. 419.

20 Zakon pro zminu i dopownennia do Konstytuciji (Osnownoho Zakonu) Ukrajinskoji RSR z 14.02.1992 r., WWR, nr 20, 1992, s. 271; za: W. Baluk, System politycz$n y$, op. cit., s. 6.

${ }_{21}$ Konstytucyjna reforma na Ukrainie, op. cit., s. 3. 
wyższą projekt ustawy „O władzy państwowej i samorządzie lokalnym na Ukrainie",22. $^{, 2}$.

Kompromisem kończącym patową sytuację pomiędzy Prezydentem i Parlamentem było podpisane 8 czerwca 1995 roku Konstytucyjne porozumienie „O podstawowych zasadach organizacji i funkcjonowania władzy państwowej i samorządu lokalnego na Ukrainie na okres do przyjęcia nowej Konstytucji Ukrainy”,23. Zgodnie z Porozumieniem Rada Najwyższa utraciła część pełnomocnictw gwarantowanych Konstytucją z 1978 roku. Szczególnie prawo zatwierdzania zaproponowanych Prezydentowi kandydatów na stanowiska Premiera, ministra spraw zagranicznych, obrony, finansów, sprawiedliwości, spraw wewnętrznych, a także prezesa Państwowego Komitetu do Spraw Ochrony Granic Państwowych, Państwowego Komitetu Celnego oraz prawo samodzielnego wyznaczania Generalnego Prokuratora Ukrainy, prezesa Służby Bezpieczeństwa Ukrainy i prezesa Zarządu Narodowego Banku Ukrainy. Dalszy przebieg zdarzeń potwierdził, że osiagnięty kompromis nie był długotrwały, ponieważ nie rozstrzygał kluczowych sprzeczności w stosunkach między Prezydentem a Radą Najwyższą ${ }^{24}$.

Na inicjowane zmiany politycznego systemu wpływały ogólnopolityczne i osobiste czynniki. Większość w Radzie Najwyższej mieli przedstawiciele sił lewicowych, którzy jeszcze nie pozbyli się pragnień utworzenia pewnej formy republiki sowieckiej, dlatego osłabienie takiej Rady Najwyższej i wzmocnienie pozycji Prezydenta można było odbierać, jako utwierdzenie niezależności. Z drugiej jednak strony, wybrany w 1994 roku Prezydentem Ukrainy, L. Kuczma już wtedy demonstrował pragnienie nieograniczonych upoważnień, jakie dawałyby możliwość wpływania na sytuację w całym kraju. Motywami, jakie pogłębiały takie jego pragnienia, było jego własne doświadczenie, jako szefa urzędu z potężnymi uprawnieniami w zakresie ustawodawstwa, jeszcze za czasów prezydenta L. Krawczuka ${ }^{25}$.

Zmiany, które odbywały się w kraju przez pięć lat i perspektywa dalszego rozkładu państwa i społeczeństwa potrzebowały już nie tylko cząstkowego

22 A. I. Kudriaczenko, op. cit., s. 125.

23 W. Baluk podaje za W. Pohoriłko nazwę: „Ugoda konstytucyjna o organizacji władzy państwowej oraz samorządzie na okres do przyjęcia nowej Konstytucji Ukrainy". W. Baluk, System polityczny, op. cit., s. 7.

24 Konstitucijnij dogowir wid 8.06.1995, Nr 1k/95-BP, WWR, 1995, nr 18, s. 133.

25 A. I. Kudriaczenko, op. cit., s. 126. 
korygowania Ustawy Zasadniczej, ale pełnowartościowej konstytucyjnej reformy.

Po pierwsze, konstytucyjnego wyznaczenia wymagał status nowopowstałego państwa, podstawy jego społecznego ustroju i głównych atrybutów. Po drugie, wprowadzenie w 1992 roku nowej dla Ukrainy instytucji Prezydenta wymagało uzgodnienia funkcji i uprawnień w trójpodziale Prezydent - Rada Najwyższa - Gabinet Ministrów (dwa ostatnie organy młode państwo dostało w spadku po URSR). Po trzecie, konieczne było stworzenie nowego systemu władzy lokalnej, ponieważ istniejące poziomy rad nie odpowiadały nowym społeczno-politycznym realiom i potrzebom zmian $\mathrm{w}$ kraju ${ }^{26}$.

Ostatnim punktem stanowienia politycznego systemu niezależnej Ukrainy było uchwalenie 28 czerwca 1996 roku przez Radę Najwyższą Konstytucji Ukrainy ${ }^{27}$.

\section{Prezydent i Rada Najwyższa w kontekście uchwalonej Konstytucji}

Uchwalona Konstytucja znacząco różniła się od projektu wniesionego przez Prezydenta na ogólnokrajowe referendum ${ }^{28}$, ale ze względu na umowy między Radą Najwyższą i Prezydentem, był on zmuszony ją podpisać. Jej uchwalenie miało zarówno pozytywne, jak i negatywne następstwa. To co najważniejsze, to wyznaczenie logiki dalszego kierunku politycznej reformy na Ukrainie ${ }^{29}$.

Model, który wprowadzała nowa Konstytucja, można określić jako republika prezydencko-parlamentarna. W rzeczywistości model ten okazał się znacznie bliższy do nieograniczonej władzy prezydenckiej, niż do klasycznego modelu prezydencko-parlamentarnego ${ }^{30}$.

26 Konstytucyjna reforma na Ukrainie, op. cit., s. 3.

27 Konstitucija Ukrajiny: Zakon wid 28.06.1996, Nr 254 k/96-BP, WWR, 1996, nr 30 , s. 141.

28 Pro probiedennja wceukrajinskoho referendum $\mathrm{z}$ pitannja prijnjattjajanowoji Konstituciji Ukrajini: Ukaz Prezidenta wid 26.06.1996, Nr 467/96 (Ukazwtratiw czinnict na podstawi Ukazu Prezidenta Nr 489/96 wid 1.07.96). - (thum. O przeprowadzeniu ogólnokrajowego referendum w zakresie przyjęcia Konstytucji Ukrainy: Dekret Prezydenta z 26.06.2006, Nr 467/96) (Dekret zmieniony na podstawie Dekretu Prezydenta nr 489/96 z 1.07.1996 r.); http://zakon1.rada.gov.ua z 15.03.2008 r.

29 Ukraina: rik z nowoju Konstitucieju: Analit. dop. Centru O. Razumkowa, Kijiw 1997, s. 8-14.

${ }^{30}$ A. I. Kudriaczenko, op. cit., s. 126. 
Z Konstytucją Prezydent Ukrainy otrzymał praktycznie pełną kontrolę nad tworzeniem Gabinetu Ministrów, powoływaniem składu centralnych organów władzy wykonawczej, a także wyznaczaniem i odwoływaniem kierowników lokalnych organów władzy wykonawczej. Podkreślano, że wraz ze stworzeniem precedensu wyznaczania i odwoływania z posad zastępców kierowników tych organów, odbyło się faktyczne przywłaszczenie nienadanego Prezydentowi w Konstytucji upoważnienia ${ }^{31}$.

Oprócz tego, Konstytucja nadała Prezydentowi także znaczne organizacyjne i kadrowe pełnomocnictwa odnośnie:

- organów władzy sądowniczej: tworzenie i likwidacja sądów, mianowanie sędziów na stanowiska, mianowanie 1/3 sędziów do składu Konstytucyjnego Sądu Ukrainy, a także przeniesione de facto i legitymizowane w Ustawie „O ustroju sądowniczym Ukrainy” wyznaczanie sędziów na stanowiska administracyjne w sądach;

- formacji wojskowych: kierownictwo w sferach bezpieczeństwa narodowego i obrony, mianowanie na stanowiska i odwoływanie ze stanowisk wyższych dowódców Sił Zbrojnych Ukrainy i innych wojskowych formacji;

- organów prawo-ochronnych: mianowanie na stanowiska za zgodą Rady Najwyższej Ukrainy i odwoływanie według własnego uznania Generalnego Prokuratora Ukrainy.

Z występowaniem takiego zakresu upoważnień Prezydenta, ukazała się nieefektywna pozycja Konstytucji, która miała odgrywać rolę mechanizmu powstrzymywania i zapobiegania pełnemu podporządkowania władzy wykonawczej Prezydentowi, co znalazło miejsce w zapisach:

- o wyznaczaniu szefów lokalnych organów administracji także na wniosek Gabinetu Ministrów (rozdział 4, art. 118);

- o wyznaczaniu kierowników centralnych organów władzy wykonawczej na wniosek Premiera Ukrainy (rozdz. 10, cz. 1, art. 106);

- o kontrasygnowaniu pewnych aktów Prezydenta podpisami Premiera lub ministra odpowiedzialnego za jego wykonanie (cz. 4, art. 106).

Powoływanie za porozumieniem kandydatów na najważniejsze stanowiska władzy wykonawczej, gdy ich odwołanie ze stanowisk zależało tylko od woli Prezydenta, świadczyło o faktycznym braku równowagi w tym zakresie na korzyść Prezydenta.

31 Ibidem, s. 127. 
Bardzo zależny charakter organów władzy wykonawczej, ich uzależnienie i podporządkowanie Prezydentowi były charakterystyczne dla pierwszych lat po przyjęciu Konstytucji.

Tworzenie Gabinetu Ministrów (Rządu) bez udziału Rady Najwyższej stworzyło sytuację, że stosunek Parlamentu do inicjatyw ustawodawczych Rządu znacznie częściej zależał od czynników sytuacyjnych. $Z$ tego powodu, nawet przy dominacji Prezydenta i jego znacznych możliwości wpływu na pozycję deputowanych nie wszystkie proponowane przez Rząd uchwały stawały się prawem ${ }^{32}$.

Szczególnie odczuwanym niedociągnięciem był brak określonego statusu parlamentarnej większości i jej związków z Rządem. Efektywna działalność Gabinetu Ministrów wymagała ustawowego zabezpieczenia ze strony Rady Najwyższej i uzyskania stabilnej prorządowej większości. Jednak Konstytucja nie wyznaczała mechanizmów, które by to umożliwiały. Rola większości ograniczała się do zatwierdzania zaproponowanej przez Prezydenta kandydatury Premiera, zatwierdzenia programu tego Gabinetu i możliwość wyrażenia jemu nieufności. W Konstytucji nie było żadnego zapisu, który dawałby parlamentarnej większości istotny wpływ na formułowanie osobowego składu Rządu i przewidywałby mechanizmy odpowiedzialności frakcji i grup deputowanych za działalność w Urzędzie wysuniętych przez nich kandydatur. Nie był przewidziany także mechanizm realizacji solidarnej odpowiedzialności parlamentarnej większości i Gabinetu Ministrów za program, który ona zatwierdziła. Natomiast cały realny istotny wpływ na formułowanie Rządu i poziomy władzy wykonawczej był w rękach Prezydenta. Faktycznie na Ukrainie funkcjonowały dwa Rządy - Gabinet Ministrów i Administracja Prezydenta. Prezydent posiadał najważniejszy wpływ na Gabinet Ministrów - zarówno konstytucyjny, jak i personalny ${ }^{33}$. Wpływ na to z pewnością miał fakt, że proces tworzenia ukraińskiej Konstytucji przebiegał, w porównaniu do doświadczeń innych krajów, w szybkim tempie.

Charakterystyczny dla Ukrainy był brak zaznaczonej wzajemności Rady Najwyższej i Rządu. Większość parlamentarna formowała się sytuacyjnie, co skutkowało tym, że uchwalana była tylko niewielka część rządowych projektów ustaw. Prawo nie było stanowione systemowo, co znowu komplikowało sytuację władzy wykonawczej.

32 A. I. Kudriaczenko, op. cit., s. 128.

33 Konstytucyjna reforma na Ukrainie, op. cit., s. 4-5. 
Uczestniczenie Prezydenta w procesie ustawodawczym (jako faktycznego szefa Gabinetu Ministrów) prowadziło do liberum veto, a także do usiłowania zewnętrznego wpływania na wewnątrz parlamentarny proces celem zabezpieczenia podporządkowania Rady Najwyższej Prezydentowi. Najbardziej wyrazistym przykładem takiego wpływu były sprawy formułowania „prorządowej większości”. Szczególnie w lutym 2000 roku, kiedy to proprezydenccy deputowani w Radzie Najwyższej zainicjowali stworzenie parlamentarnej większości i na drodze siłowej usunęli z kierownictwa Rady Najwyższej przedstawicieli lewicowych sił politycznych (O. Tkaczenkę na stanowisku Przewodniczącego Rady zmienił I. Pluszcz). Uzyskana większość, do której weszli przedstawiciele centrowych i prawo-centrowych frakcji, delegowała swoich przedstawicieli do składu Gabinetu Ministrów, na którego czele stał Wiktor Juszczenko ${ }^{34}$.

Jednak taka większość od początku nie mogła być trwała, ponieważ, po pierwsze, powstała ona ,pod konkretny projekt” - zmiany kierownictwa Rady Najwyższej z użyciem narzędzi politycznego nacisku i jawnego podkupywania innych deputowanych ${ }^{35}$; po drugie, należały do niej ideologicznie różne siły, a ich interesy rozmijały się z interesami Prezydenta i jego otoczenia. To wszystko przyśpieszyło rozpad większości, który nastapił wkrótce na skutek ,sprawy Gonzadze” i dymisji Rządu W. Juszczenki $^{36}$.

Obydwie strony konfliktu wykorzystywały wszystkie możliwości i zasoby. Rada Najwyższa starała się ogłosić początek procedury impichmentu Prezydenta Ukrainy. We wrześniu 1997 roku możliwość impichmentu rozpatrywała Komisja Rady Najwyższej do spraw polityki prawnej i reformy sądowo-prawnej. Prezydenckie struktury, w tym samym czasie, analizowały warianty rozwiązania Parlamentu. Istnienie i scenariusz przedłużenia upoważnień Rady Najwyższej na rok służyło, jak uważali niektórzy deputowani, pozbawieniu Parlamentu legitymizacji ${ }^{37}$. Przy czym żadna z wymienionych inicjatyw, a także żadna zmiana do Konstytucji, nie została wcielona w życie.

Nowa Konstytucja sformułowała prawne zasady nowej organizacji władzy państwowej, które jednak, osłabiły jej stabilność i stworzyły

34 A. I. Kudriaczenko, op. cit., s. 130.

35 Ibidem, s. 130.

36 Ibidem, s. 130.

37 O. Dmitricziewa, Parlamentarni politiczeskich wziatok ne berut, „Kyewskye wedomosti", 2.07.1997. 
podwójność podporządkowania władzy wykonawczej. Dlatego całkiem logiczne jest, że konflikt między najwyższymi instytucjami władzy - Prezydentem i Radą Najwyższą - bardzo się rozwiną ${ }^{38}$.

\section{Zmiany w Konstytucji Ukrainy po 1999 roku}

Status quo w stosunkach między stronami trwał do końca 1999 roku, kiedy Prezydent L. Kuczma został wybrany na drugą kadencję. Już podczas kampanii wyborczej rozumiano, że zainicjuje on proces reformowania Konstytucji Ukrainy, wykorzystując wszystkie dostępne środki. W przedwyborczym programie kandydata na Prezydenta Ukrainy L. Kuczmy znajdował się zapis odnośnie Parlamentu „dwuizbowy parlament: politycznie odpowiedzialna większość w parlamencie na bazie szerokiej społecznej koalicji: rząd parlamentarnej większości, narodowego porozumienia i odpowiedzialności..."39.

15 stycznia 2000 roku Prezydent L. Kuczma wydał Dekret „O ogłoszeniu ogólnoukraińskiego referendum z inicjatywy narodu”, którego zakres dotyczył:

- rozszerzenia podstaw dla rozwiązania Parlamentu przez Prezydenta (w przypadku niemożliwości sformułowania trwałej większości i niezatwierdzenia przez trzy miesiące budżetu państwa);

- ograniczenia immunitetu deputowanych;

- zmniejszenia ilości deputowanych do Rady Najwyższej z 450 do 300 osób;

- wprowadzenia dwuizbowego Parlamentu ${ }^{40}$.

W związku z wątpliwymi podstawami prawnymi zwołania referendum, a także konieczności zdobycia poparcia obywatelskiego w celu uzasadnienia zakresu referendum, prezydenckie struktury były ogarnięte szerokozakrojoną kampanią propagandową za prezydencką inicjatywą i dyskredytującą Radę Najwyższą ${ }^{41}$.

38 A. I. Kudriaczenko, op. cit., s. 131.

39 Wibori. Do i pislja (chronologija, peredwiborni programi, wislowljuwannja

L. D. Kuczmy), Kijiw 2000, s. 27.

40 Pro progoloszennja wsenarodnoho referendum za narodnoju iniciatywoju: Ukaz Prezydenta Ukrajiny Nr 65 z 15 stycznia 2000 r.

${ }^{41}$ A. I. Kudriaczenko, op. cit., s. 133. 
Zgodnie z oficjalnymi danymi, 16 kwietnia 2000 r. zdecydowana większość obywateli poparła w referendum zaproponowane przez Prezydenta zmiany. W ocenie zarówno ukraińskich, jak i zagranicznych ekspertów, referendum odbyło się z naruszeniem prawa i przy użyciu administracyjnych środków, co dało możliwość poddania pod wątpliwość jego rezultatu ${ }^{42}$.

Pomimo, że 16 kwietnia 2000 r. ogłoszono zaakceptowanie przez naród wniesionych na referendum propozycji, możliwość pozaparlamentarnej zmiany Konstytucji zgodnie z postanowieniami referendum została zablokowana przez Konstytucyjny Sąd Ukrainy. Decyzją z 27 września 2000 r. Sąd Konstytucyjny zaznaczył, że w razie zaaprobowania na referendum proponowanych zmian powstaje obowiązek ich rozpatrzenia przez organy władzy państwowej i uchwalenia odpowiednich decyzji w porządku wyznaczonym przez Konstytucję Ukrainy, zgodnie z rozdziałem XIII „Wprowadzanie zmian do Konstytucji”, i ustawami Ukrainy. Także zmiany nie mogą być implementowane bezpośrednio do tekstu Konstytucji bez odpowiedniej decyzji Parlamentu ${ }^{43}$.

W rezultacie referendum Prezydent Kuczma utworzył Komisję do przygotowania zmian do Konstytucji Ukrainy i innych projektów ustaw, które wynikały z decyzji podjętych na referendum. Na czele tej Komisji stanęli wspólnie szef Administracji Prezydenta Ukrainy W. Łytwyn i pierwszy zastępca Przewodniczącego Rady Najwyższej W. Medwiedczuk. Próba zatwierdzenia odpowiedniego projektu przez Parlament zakończyła się niepowodzeniem w wyniku głosowania 18 stycznia $2001 \mathrm{r}^{44}$

We wrześniu 2001 r. Prezydent Ukrainy wydał Rozporządzenie „O przygotowaniu projektu koncepcji reformowania systemu politycznego Ukrainy" "45, zgodnie z którym grupa naukowców i przedstawicieli organów władzy przygotowała i przedstawiła na naukowych konferencjach odpowiednią koncepcję. Jednak nie wniosła ona żadnych praktycznych wskazówek, co do reformowania systemu ${ }^{46}$.

Kolejna inicjatywa Prezydenta odnośnie wprowadzenia na Ukrainie reformy politycznej była publicznie ogłoszona w wystappieniu L. Kuczmy

42 Ibidem, s. 133.

43 Ibidem, s. 133.

44 Pro wnesennja zmin do Konstytuciji Ukrajiny za rezultatami wseukrajinskoho referendum za narodnoju iniciatiwiju: Projekt Zakonu nr 5300 z 25.04.2000 r.

45 Pro pidgotowku projektu Koncepciji reformuwannja politicznoji systemy Ukrajiny: Rozporjadżennja Prezydenta Ukrajiny Nr 73 z 27 września 2001 r.

46 A. I. Kudriaczenko, op. cit., s. 133. 
do narodu w 11 rocznicę Niezależności Ukrainy 24 sierpnia 2002 r., znalazły się $\mathrm{w}$ nim między innymi propozycje ${ }^{47}$ :

- przejścia do parlamentarno-prezydenckiej republiki, co przewidywało tworzenie rządu przez większość parlamentarną i zmniejszenia uprawnień Prezydenta na korzyść Rady Najwyższej;

- uchwalenia nowej ustawy wyborczej do Rady Najwyższej, zgodnie z którą wybory odbywałyby się wyłącznie na listy partyjne ${ }^{48}$.

W politycznych kołach inicjatywa Prezydenta była rozumiana niejednoznacznie. Cześć polityków uważała, że Kuczma tak naprawdę nie ma rzeczywistego zamiaru przeprowadzić politycznej reformy, a próbuje w taki sposób przechwycić hasła opozycji i zarazem polityczną inicjatywę. Tezę tę potwierdzały argumenty, że Głowa Państwa niejednokrotnie negatywnie oceniał perspektywę przejścia Ukrainy do republiki parlamentarno-prezydenckiej, krytykował proporcjonalny system wyborczy i negował konieczność uchwalenia odpowiedniej Ustawy wyborczej ${ }^{49}$. Podkreślano, że w maju 2002 roku grupa opozycyjnych deputowanych (wybranej w tym roku Rady Najwyższej: O. Moroz, P. Simonenko, A. Matwienko i inni) zgłosiła do Rady Najwyższej projekt ustawy o zmianach do Konstytucji. Jej sens odpowiadał propozycji Prezydenta, dodatkowo gwarantowała prawa parlamentarnej opozycji, pozbawienie upoważnień deputowanego, wybranego z listy partyjnej (bloku), w przypadku jego przejścia do innej frakcji. Projekt otrzymał pozytywną opinię Sądu Konstytucyjnego i mógł być rozpatrzony przez Radę Najwyższą. Jednocześnie podział sił w Parlamencie faktycznie pozbawiał inicjatorów projektu szans na jego przyjęcie - przeciw niemu występowali przedstawiciele proprezydenckich frakcji, a także część parlamentarnej opozycji ${ }^{50}$.

25 grudnia 2002 r. Prezydent Kuczma nazwał rozpoczętą polityczną reformę głównym wydarzeniem 2002 roku i jednym z państwowych priorytetów na rok 2003 oraz zaznaczył, że w razie nieprzeprowadzenia

47 Ibidem, s. 134.

48 W tym czasie obowiązywała „Ustawa o wyborach deputowanych ludowych Ukrainy” z 24.09.1997 r. W systemie wyborczym większościowo-proporcjonalnym, połowa Parlamentu wybierana była w ogólnopaństwowym okręgu wyborczym według list partyjnych, zaś druga połowa w jednomandatowych okręgach wyborczych". Zakon pro wybory narodnych deputatiw Ukrainy z 24.09.1997 r., „Hołos Ukrainy” z 25.09.1997; zob. A. J. Madera, Między Rosja a Europq. Ukraina na rozdrożu, Rzeszów 2000, s. 91-102.

49 A. I. Kudriaczenko, op. cit., s. 134.

50 Ibidem, s. 134. 
reformy do czasu następnych wyborów prezydenckich, nie będzie ona wprowadzona w ogóle $\mathrm{e}^{51}$.

Potwierdzenie poważnych zamiarów Prezydenta, co do reformy konstytucyjnej zmieniło nastawienie wśród pozostałych politycznych sił, co znacznie zwiększyło szanse na szybkie wprowadzenie reformy. Jednak poglądy poszczególnych deputowanych odnośnie detali reformy znacznie się różniły. Rada Najwyższa uchwaliła postanowienie dotyczące stworzenia Tymczasowej specjalnej komisji do opracowania projektów ustaw o wprowadzeniu zmian do Konstytucji Ukrainy ${ }^{52}$. W skład komisji weszło 21 deputowanych - przedstawicieli 12 z 13 frakcji i grup parlamentarnych (nie wszedł do niej przedstawiciel grupy „Europejski wybór”). Na czele komisji stanęli wspólnie pierwszy zastępca Przewodniczącego Rady Najwyższej G. Wasiliew i lider frakcji SPU (Socjalistyczna Partia Ukrainy) O. $\mathrm{Moroz}^{53}$.

4 lutego 2003 roku odbyła się trzecia sesja Rady Najwyższej Ukrainy. W porządku dziennym obrad znalazła się sprawa wprowadzenia zmian do Konstytucji Ukrainy. Tego dnia Prezydent Kuczma na konferencji prasowej oświadczył, że ma zamiar do końca miesiąca złożyć w Parlamencie własny projekt ustawy. Motywował swój krok brakiem rzeczywistych postępów Rady Najwyższej w tym kierunku, oprócz tego, że w tym dniu spiker Parlamentu W. Łytwyn nazwał wprowadzenie politycznej reformy głównym zadaniem bieżącej sesji parlamentu. Jednocześnie w Narodowym Instytucie Badań Strategicznych odbył się z udziałem niezależnych ekspertów „okragły stół” w sprawie reformy systemu politycznego, co oznaczało początek szeroko zakrojonej prezydenckiej kampanii do wprowadzenia zmian do Konstytucji ${ }^{54}$.

5 marca 2003 roku Prezydent Ukrainy upublicznił swój punkt widzenia politycznej reformy ogłoszonej 24 sierpnia 2002 roku. Główne zasady tej reformy były następujące:

- wprowadzenie dwuizbowego Parlamentu, gdzie niższa izba będzie wybierana spośród kandydatów partii politycznych systemem proporcjonalnym, wyższa - składać się będzie z przedstawicieli 24 obwodów - województw (областей), Autonomicznej Republiki Krymu, Kijowa

51 Ibidem, s. 134.

52 Postanowi Werchownoji Rady Ukrajiny Nr 381-IV z 26.12.2006 r.

53 A. I. Kudriaczenko, op. cit., s. 135.

54 Ibidem, s. 135. 
i Sewastopola (po trzech deputowanych z każdej jednostki administracyjno-terytorialnej);

- zmniejszenie ogólnej liczby deputowanych Parlamentu z 450 do 300 osób;

- nadanie większości niższej izby Parlamentu prawa proponowania Prezydentowi i zatwierdzania kandydatury Premiera, zatwierdzania składu Gabinetu Ministrów (zaproponowanego przez Premiera) i podawanie rządu do dymisji;

- nadanie Prezydentowi prawa rozwiązania Parlamentu w wypadku, kiedy deputowani w przeciagu wyznaczonego konstytucyjnie terminu nie zdążą sformułować większości, jak też większość nie będzie w stanie utworzyć rządu, a także Parlament nie zdąży w wyznaczonym terminie przyjąć budżetu;

- nadanie praw Prezydentowi odnośnie wyznaczania ministra spraw zagranicznych, ministra obrony, ministra spraw wewnętrznych, ministra do spraw nadzwyczajnych, a także kierowników siłowych i kontrolnych struktur; prawo Prezydenta wyznaczania szefów obwodowej administracji państwowej (na wniosek Premiera);

- wybór Prezydenta, Parlamentu i lokalnych rad na jednakowy okres - pięciu lat (dwie ostatnie instytucje w momencie wydania oświadczenia były wybierane na cztery lata), przeprowadzenia wszystkich wyborów w różnych terminach (dwie ostatnie instytucje w tym momencie były wybierane w tym samym dniu), ale w czasie jednego roku;

- odnośnie wyników rezultatów Referendum: rezultaty referendum w ww. części i tej, która odnosi się do zmian do Konstytucji Ukrainy, nabierają mocy bez zatwierdzenia przez jakikolwiek inny organ władzy.

Zgodnie z dekretem Prezydenta Ukrainy nr 197 z 6 marca 2003 roku odpowiedni projekt ustawy miał być poddany ogólnonarodowej konsultacji i równocześnie złożony przez Prezydenta do Rady Najwyższej „dla uprzedniego zapoznania się i omówienia"55. Powyższy projekt został zarejestrowany w Radzie Najwyższej Ukrainy pod nr 3207.

W trakcie „ogólnonarodowej dyskusji” na adres Administracji Prezydenta i Ministerstwa Sprawiedliwości masowo przychodziły odezwy pracowniczych kolektywów, lokalnych rad i indywidualnych obywateli popierających prezydencką inicjatywę. Prawdziwym celem takich konsultacji, według większości polityków i ekspertów było stworzenie pod-

55 Ibidem, s. 136. 
stawy do ogłoszenia referendum dla wprowadzenia zaproponowanych przez Prezydenta zmian do Konstytucji na wypadek, jeśli nie zrobi tego Rada Najwyższa ${ }^{56}$.

Według danych Ministerstwa Sprawiedliwości, poparcia dla projektu udzieliło ponad 500 tys. obywateli, a w konsultacjach propozycji Prezydenta wzięło udział ponad 823 tys. ${ }^{57}$ Jednak według danych z badań socjologicznych, po miesiącu konsultacji jedna trzecia obywateli (34,3\%) oświadczyła, że zapoznała się z prezydenckimi inicjatywami, a tylko $8 \%$ - wzięło udział w konsultacjach ${ }^{58}$.

Dane z socjologicznych badań wskazywały, że nie znalazły poparcia propozycje Prezydenta odnośnie dwuizbowego parlamentu i przyznaniu Prezydentowi połowy, a nie jednej trzeciej składu Sądu Konstytucyjnego. Natomiast poparcie zdobyły takie propozycje, jak przekazanie Radzie Najwyższej upoważnień do formowania rządu, rozszerzenia praw Prezydenta w zakresie rozwiązania Parlamentu, przeprowadzania wyborów władz w tym samym roku i na taki sam okres - pięciu lat, wprowadzenia imperatywnego mandatu itp. ${ }^{59}$

Nastawienie Parlamentu do projektu także było niejednoznaczne. Szereg pozycji nie sprzyjało, nie tylko przedstawicielom opozycji, ale i części lojalnych Prezydentowi deputowanych. Szczególnie takie pozycje, jak zaproponowanie dwuizbowego parlamentu z mniejszą ilością deputowanych oraz możliwość przyjęcia ustaw bezpośrednio za pomocą referendum. Taka sytuacja praktycznie uniemożliwiała podtrzymanie prezydenckiego projektu konstytucyjną większością Rady Najwyższej.

15 kwietnia 2003 roku w Parlamencie odbyło się wygłoszenie dorocznego Orędzia Prezydenta Ukrainy do Rady Najwyższej ${ }^{60}$. Część orędzia, poświęcona reformie politycznej, stanowiła powtórzenie propozycji przedstawianych wcześniej przez Prezydenta. Nowością było zaakcentowanie, że reforma polityczna miała być zrealizowana na podstawie skali administracyjnej reformy, która przewidywała radykalne zmiany w strukturze

56 Ibidem, s. 137.

57 A. I. Kudriaczenko, op. cit., s. 137 za: Interfaks-Ukraina 8.05.2003.

58 Ibidem: za danymi $\mathrm{z}$ badania socjologicznego Centrum Razumkowa 21-29.04.2003 r.

59 Ibidem, s. 137.

60 Pro wnutriszczie i zownisznie stanowysze Ukrajiny w 2002 roci: Poslannja Prezydenta Ukrajiny do Werchownoji Rady Ukrajiny, „Zwernennja wid” 15.04.2003, nr 10. 
i funkcjach centralnych i lokalnych organów władzy wykonawczej oraz wzmocnienie niezależności lokalnego samorządu.

15 maja 2003 roku zakończył się czas przeznaczony przez Prezydenta na konsultacje ogólnonarodowe, co do jego propozycji reformowania systemu politycznego Ukrainy. Następnego dnia Prezydent spotkał się z czołowymi politologami Ukrainy i wyłożył swoje uwagi na temat reformy. Jeszcze raz potwierdził swoją ideę dwuizbowego Parlamentu, jednak oświadczył, że jest gotowy do kompromisu w tej sprawie. Zdecydowanie wypowiedział się za przeprowadzaniem wyborów na podstawie list partyjnych ${ }^{61}$.

19 czerwca 2003 roku Prezydent Kuczma wystąpił z orędziem do narodu, w którym powiadomił o złożeniu w Parlamencie projektu ustawy o wniesieniu zmian do Konstytucji (projekt nr 3207). Projekt przewidywał pewne zwiększenie uprawnień Parlamentu odnośnie tworzenia rządu, ale zapewniał Prezydentowi kontrolę nad kilkoma najważniejszymi centralnymi organami władzy wykonawczej i nad całym systemem lokalnych organów władzy wykonawczej. Przy czym istotnie rozszerzał możliwość czasowego ograniczania uprawniwń Parlamentu. Określenie zaproponowanego w projekcie modelu systemu państwa, jako ,parlamentarno-prezydencki” było dosyć wątpliwe ${ }^{62}$.

Prezydent poszedł na ustępstwa parlamentarzystom, wycofując się z trzech elementów politycznej reformy, wymienianych wcześniej:

- wprowadzenie dwuizbowego Parlamentu;

- zmniejszenie ilości deputowanych;

- możliwości przyjęcia ustaw przez referendum.

Jednak pozostały takie zasady, jak:

- podział ministrów na tych, których wyznacza Parlament i tych, których wyznacza Prezydent;

- podwyższenia wieku emerytalnego sędziów Sądów Konstytucyjnego i Najwyższego;

- samodzielne wyznaczanie przez Prezydenta kierowników wszystkich centralnych organów władzy wykonawczej, którzy nie należeli do składu Gabinetu Ministrów (w wypadkach przewidzianych Konstytucją);

- przeprowadzania wyborów do wszystkich organów władzy i samorządu lokalnego w jednym roku.

61 A. I. Kudriaczenko, op. cit., s. 138.

62 Ibidem, s. 139. 
Według opozycji propozycje Prezydenta nie były zgodne z logiką przejścia do republiki parlamentarno-prezydenckiej i były ukierunkowane na prolongatę upoważnień Kuczmy.

Jednocześnie w rezultacie działalności specjalnej komisji do opracowania projektu ustawy odnośnie wprowadzenia zmian do Konstytucji Ukrainy został przygotowany tekst nowego projektu ustawy, który po jego podpisaniu przez odpowiednią ilość deputowanych został wniesiony do Parlamentu i 1 lipca 2003 r. zarejestrowany pod nr 3207-1. W ten sposób, latem 2003 roku na rozpatrzenie Parlamentu czekały dwa projekty ustaw, które przewidywały różne warianty reformy konstytucyjnej ${ }^{63}$.

Projekt parlamentarny uwzględniał większość propozycji Prezydenta. Przy czym większość uzgodnień wynikała z konsensusu przedstawicieli frakcji większości i opozycji. Tym co deputowanym kategorycznie nie odpowiadało, była propozycja przeprowadzania wszystkich wyborów w jednym roku. Opozycja parlamentarna (przede wszystkim frakcje „Nasza Ukraina” i BJUT ${ }^{64}$ ) widziała w tym, usiłowanie Kuczmy wydłużenia okresu swojego utrzymywania się przy władzy ${ }^{65}$.

Już jesienią pojawił się jeszcze jeden projekt zmian do Konstytucji. 4 września 2003 r. pod rozpatrzenie Parlamentu został wniesiony podpisami 233 deputowanych projekt Ustawy Ukrainy „O wprowadzeniu zmian do Konstytucji Ukrainy”, zarejestrowany pod nr 4105. Projekt ten był rezultatem porozumienia między Szefem Prezydenckiej Administracji W. Miedwiedczukiem z liderami mających większość lewicowych frakcji Parlamentu Komunistycznej Partii Ukrainy (KPU) i Socjalistycznej Partii Ukrainy (SPU) ${ }^{66}$.

Według ekspertów, głównymi celami, które przyświecały inicjatorom wniesienia nowego projektu były:

- zmniejszenia upoważnień wybieranego w 2004 roku Prezydenta Ukrainy (którym, z dużym prawdopodobieństwem mógł zostać W. Juszczenko);

- porozumienie dla utrzymania się w polityce starych politycznych elit, w wypadku zmiany Prezydenta;

63 Konstytucyjna reforma na Ukrainie, op. cit., s. 10-14.

64 Blok Juli Tymoszenko.

65 A. I. Kudriaczenko, op. cit., s. 140.

66 P. Simonenko, Miedwieczuk powiedzial, że ma petnomocnictwo Prezydenta na konsultacje z opozycja, http://www.pravda.com.ua. 
- przeniesienia centrum politycznej władzy do Parlamentu (na czele z W. Miedwieczukiem - Socjaldemokratyczna Partia Ukrainy, przewidującej zajęcie w nim kluczowej pozycji);

- wprowadzenia zamętu w szeregi opozycji ${ }^{67}$.

Ale nawet proprezydencka parlamentarna większość, nie zważając na zebrane podpisy deputowanych, odnosiła się do projektu niejednoznacznie, ponieważ siły polityczne, mając własnych kandydatów na Prezydenta, nie były zainteresowane znacznym osłabieniem jego pozycji. Fakt ogłoszenia projektu przez liderów SPU i KPU oraz szefa prezydenckiej Administracji nie gwarantował jego poparcia przez członków odpowiednich frakcji ${ }^{68}$.

24 grudnia 2003 roku projekt ustawy nr 4105 w warunkach nadzwyczajnie konfliktowej sytuacji i niekonsekwentnie organizowanego oraz przeprowadzonego głosowania został uchwalony przez Radę Najwyższą. W związku z koniecznością zabezpieczenia projektu większym poparciem członków Parlamentu do jego tekstu były wnoszone poprawki, w następstwie czego po poprzednim uchwaleniu był on ponownie poprawiony na wniosek Sądu Konstytucyjnego ${ }^{69}$.

Otrzymanie pozytywnej opinii Sądu Konstytucyjnego (Nr 1 z 16.03.2004 r.) dla tego wariantu projektu, umożliwiło 8 kwietnia 2004 r. przeprowadzenie głosowania nad jego ostatecznym uchwaleniem. Za przyjęciem projektu głosowało 294 deputowanych, co oznaczało jego nieprzyjęcie przez Radę Najwyższą. Jednak wkrótce po tym, pojawił się pomysł kontynuowania pracy nad konstytucyjną reformą poprzez dalsze rozpatrywanie projektu nr 4180. Projekt Ustawy Ukrainy „O wprowadzeniu zmian do Konstytucji Ukrainy” nr 4180, który wreszcie miał szanse być uchwalonym, był wniesiony do rozpatrzenia przez Radę Najwyższą 19 września 2003 roku przez grupę deputowanych narodowych ${ }^{70}$.

W głównych punktach projekt przypominał projekt ustawy $\mathrm{nr} 4105^{71}$, jednak miał także znaczne różnice, które znalazły się w jego przejścio-

67 A. I. Kudriaczenko, op. cit., s. 140.

68 Ibidem, s. 140.

69 Ibidem, s. 141.

70 Ibidem, s. 141.

71 O. Szmorhun uważa wręcz, że „W rzeczywistości projekt, który przeszedł ekspertyzę Sądu Konstytucyjnego, nie jest niczym innym, aniżeli nieco zmienionym pod naciskiem okoliczności (ogólnonarodowe wybory prezydenckie zamiast parlamentarnych) projektem o numerze 4105/4180, który swego czasu zaproponował Kuczma, a przygotowali jego poplecznicy po to, aby władzę na Ukrainie jeszcze bardziej pozba- 
wych ustawach. Zmiana w porównaniu z poprzednim projektem przewidywała przeprowadzenie kolejnych wyborów do Parlamentu w 2007 roku (a nie w 2006) i wybrania Prezydenta Ukrainy przez Radę Najwyższą w październiku 2004 roku, a także wybranie następnego Prezydenta Ukrainy przez parlament nowej kadencji w 2007 roku $^{72}$.

22 września 2003 roku projekt był skierowany za podpisami 250 deputowanych do zaopiniowania przez Sąd Konstytucyjny, świadczyło to o możliwości jego uchwalenia. Zgodnie z opinią Sądu Konstytucyjnego (Nr 3 z 10.12.2003 r.) projekt ustawy został uznany za odpowiadający wymogom $\S \S 157-158$ Konstytucji Ukrainy.

Aktywne przygotowanie projektu nr 4180 do przyjęcia przez Radę, rozpoczęło się po nieudanej próbie ostatecznego przyjęcia projektu ustawy nr 4105. Już na tym etapie projekt zaznał istotnych zmian. Podczas przygotowań do rozpatrzenia w Parlamencie, tymczasowa specjalna komisja usunęła z projektu zapis o wyborze Prezydenta Ukrainy przez Parlament. Na tym stadium wyłączono osobne zapisy, które odnosiły się do: podstaw czasowego wstrzymania upoważnień deputowanego; zmniejszenia listy członków rządu i kierowników centralnych organów władzy wykonawczej wyznaczanych przez Parlament na wniosek Prezydenta; ustawy o możliwości powoływania przez Parlament tymczasowych komisji; skorygowano listę podstaw dla rozwiązania Parlamentu; usunięto zapisy, które cofały mianowania sędziów sądów całej jurysdykcji, a także wniesiono inne mniej istotne korekty. Projekt przewidywał przeprowadzenie wyborów Prezydenckich w 2004 roku i Rady Najwyższej w 2006 roku, na cały okres kadencji.

Po burzliwych i trywialnych parlamentarnych dyskusjach, Rada Najwyższa 23 czerwca 2004 r. przyjęła rozporządzenie o uchwaleniu tego projektu ustawy i skierowania go do Sądu Konstytucyjnego dla zaopiniowania, koniecznego dla jego ostatecznego uchwalenia ${ }^{73}$. Swoim wnioskiem nr 2 z 12 października 2004 r. Sąd Konstytucyjny uznał projekt ustawy z wniesionymi do niego poprawkami za zgodny z wymogami $\S \S 157-158$ Konstytucji Ukrainy.

wić kontroli”. O. Szmorhun, Reforma konstytucyjna w Ukrainie: problem projektu zorientowanego narodowo, „Nowa Ukraina. Zeszyty historyczno-politologiczne” 2006, nr 1, Kraków 2006, s. 150.

${ }_{72}$ A. I. Kudriaczenko, op. cit., s. 141.

73 Ibidem, s. 142. 


\section{Nowela konstytucyjna z 8 grudnia 2004 roku}

Dalsze losy projektu i jego uchwalenia związane były z prezydenckimi wyborami w 2004 r. i masowymi akcjami protestów obywatelskich przeciw nieprawidłowościom i fałszerstwom podczas głosowania 21 listopada 2004 r. oraz z ogłoszeniem sfałszowanych rezultatów 24 listopada. W swoich umowach inicjatorzy projektu porozumieli się co do głosowania za odpowiednim projektem ustawy w zamian za podjęcie decyzji o wniesieniu pewnych korekt w prawodawstwie z zakresu wyboru Prezydenta Ukrainy ${ }^{74}$.

Pozytywne głosowanie sił opozycyjnych za tym projektem było umową, zgodnie z którą część proprezydenckich sił była gotowa głosować za projektem ustawy „O wyjątkowym zastosowaniu Prawa Ukrainy „O wyborze Prezydenta Ukrainy" przy powtórnym głosowaniu 26 grudnia 2004 roku", który uniemożliwiał wykorzystanie znacznej części mechanizmów fałszerstwa, stosowanych w poprzednich turach wyborów ${ }^{75}$.

Jednak nawet przy takiej ugodzie, projekt nr 4180 w ostatniej wersji zaakceptowanej przez Konstytucyjny Sąd Ukrainy, nie miał wystarczającego poparcia. W celu zapewnienia takiego poparcia odbyło się nowe korygowanie tekstu projektu. Podczas głosowania 8 grudnia 2004 roku, do przyjęcia w całości był zaproponowany tekst projektu, jaki zawierał istotne zmiany w porównaniu z wariantem rozpatrywanym przez Sąd Konstytucyjny.

Główne zmiany wniesione przed ostatecznym głosowaniem dotyczyły przywrócenia uprawnień Prezydenta Ukrainy odnośnie wyznaczania i odwoływania szefów lokalnej administracji państwowej, połowy składu Zarządu Narodowego Banku Ukrainy, a także powrót do porządku formowania Sądu Konstytucyjnego Ukrainy, wyznaczonego obecną Konstytucją ${ }^{76}$.

Niezważając na wniesione poprawki, Parlament przegłosował przyjęcie projektu w całości, po czym projekt w sali posiedzeń Rady Najwyższej podpisany przez Przewodniczącego Rady Najwyższej i obecnego na posiedzeniu Prezydenta Ukrainy, stał się Ustawą. Jednakże, przy głosowaniu zostało naruszonych szereg norm proceduralnych ${ }^{77}$ :

- ,pakietowe” głosowanie nie przewidziane Konstytucją Ukrainy;

- do tekstu projektu ustawy o zmianach do Konstytucji, w procesie konsultacji i uchwalania wniesiono istotne zmiany (co jest niedopuszczalne

$\begin{array}{ll}74 & \text { Ibidem, s. } 142 . \\ 75 & \text { Ibidem, s. } 142 . \\ 76 & \text { Ibidem, s. } 143 . \\ 77 & \text { Ibidem, s. } 143 .\end{array}$ 
po otrzymaniu opinii Sądu Konstytucyjnego i wymaga zgodnie z prawem ponownego złożenia projektu w tym organie).

Wszystko to mogło poddać w wattpliwość legalność wniesionych do Konstytucji zmian.

Ustawa o zmianie Konstytucji Ukrainy została uchwalona przez RN 8 grudnia 2004 r., z zastrzeżeniem długiego vacatio legis: większość przepisów miała wejść w życie 1 września 2005 r. - jeśli do tego czasu zostałaby przyjęta nowelizacja konstytucji dotycząca samorządu, w przeciwnym wypadku 1 stycznia 2006 r., zaś część - z chwilą ukonstytuowania się RN wybranej w 2006 r. $^{78}$

Najważniejsze dla funkcjonowania Państwa zapisy, które znalazły się w noweli konstytucyjnej przedstawiono poniżej:

- Mandat deputowanego ludowego RN. Nowela z 8 grudnia 2004 r. przewiduje, że mandat deputowanego ludowego wygasa przed terminem m.in. w przypadku nieprzystapienia deputowanego do klubu parlamentarnego partii politycznej albo koalicji wyborczej partii politycznych, z której rekomendacji został wybrany, albo w przypadku wystapienia $\mathrm{z}$ takiego klubu. Wygaśnięcie z mocy prawa mandatu deputowanego ludowego stwierdza najwyższy organ wykonawczy partii politycznej albo koalicji wyborczej partii politycznej, z mocą od dnia takiego rozstrzygnięcia.

- Rządowa koalicja parlamentarna w RN. Nowela z 8 grudnia 2004 r. formalizuje tryb tworzenia się rządowej koalicji parlamentarnej. W ciagu miesiąca od dnia pierwszego posiedzenia $\mathrm{RN}$ albo od dnia zaprzestania działalności dotychczasowej koalicji rządowej tworzy się rządowa koalicja parlamentarna, obejmująca większość konstytucyjnego składu RN. Proponuje ona Prezydentowi kandydata na Premiera oraz kandydatów na członków Gabinetu Ministrów. W razie nieutworzenia w tym trybie rządowej koalicji parlamentarnej Prezydent może zarządzić rozwiązanie Rady Najwyższej.

- Gabinet Ministrów. Nowela z 8 grudnia 2004 r. przewiduje, że Premier, minister obrony i minister spraw zagranicznych powoływani są przez Radę Najwyższą na wniosek Prezydenta, pozostali zaś członkowie Gabinetu Ministrów - na wniosek Premiera. Rada Najwyższa ma prawo odwołania osób powołanych na te stanowiska. Ponadto przewiduje się, że Gabinet Ministrów będzie ponosił odpowiedzialność zarów-

78 K. Bałon, Podstawowe problemy reformy konstytucji Ukrainy (ustawa z 8 grudnia 2004 r.), w: S. Dębski (red.), „Biuletyn Polskiego Instytutu Spraw Międzynarodowych”, nr 93 (338), 22 grudnia 2005. 
no przed RN, jak i przed Prezydentem. Prezydent utrzymuje prawo do wydawania dekretów i rozporządzeń podlegających wykonaniu na terytorium całej Ukrainy i prawo inicjatywy ustawodawczej, a będzie też miał prawo do wszczęcia postępowania o udzielenie wotum nieufności wobec Gabinetu Ministrów.

- Prokuratura. Nowela przewiduje poszerzenie kompetencji prokuratury o sprawowanie nadzoru nad przestrzeganiem praw i wolności człowieka i obywatela przez organy władzy wykonawczej, organy samorządu lokalnego, przedstawicieli i urzędników tych organów. Prawo powoływania i odwoływania stojącego na czele prokuratury Prokuratora Generalnego, za zgodą Rady Najwyższej, zachował Prezydent ${ }^{79}$.

1 stycznia 2006 roku przyjęte 8 grudnia 2004 roku Prawo „O wprowadzeniu zmian do Konstytucji Ukrainy” uprawomocniło się. 25 marca 2006 r. uprawomocniły się także te normy Ustawy, które odpowiednio do jej Przejściowych zasad miały nabrać mocy po nabyciu upoważnień nowoobranej Rady Najwyższej. Konstytucyjna reforma stała się konstytucyjno-prawną rzeczywistością ${ }^{80}$.

\section{Podsumowanie}

Na Ukrainie, która podlega ciagłym walkom o wpływ polityczny poszczególnych frakcji, proces reformy konstytucyjnej wciąż trwa. Niestety jest on uzależniony od sytuacji politycznej, która nie jest na tyle stabilna, aby decyzje w tym zakresie miały charakter uniwersalny, nieuwzględniający partykularnych interesów partyjnych.

Proces wyboru polityki zagranicznej zmierza ku orientacji euroatlantyckiej, co także musi znaleźć swoje odzwierciedlenie w tekście Konstytucji Ukrainy.

Doświadczenie postkomunistycznego odtwarzania państwa i realizacji kursu europejskiego i euroatlantyckiego w Polsce może być modelem dla Ukrainy. Przy podobnej jak na Ukrainie początkowej sytuacji (uzyskanie Niepodległości, sytuacja ekonomiczna) Polska została już członkiem NATO i UE i stała się jednym z najszybciej rozwijających się demokracji w Europie Wschodniej. W kontekście danej problematyki, należy podkreślić, że konstytucyjny proces w Polsce był podporządkowany demokratyzacji władzy.

79 Ibidem.

80 A. I. Kudriaczenko, op. cit., s. 143. 
W latach 1989-1992 w Polsce w kontekście wprowadzenia nowej Konstytucji szczególną uwagę kierowano na rozwój społeczeństwa obywatelskiego, politycznego pluralizmu, ochrony różnych form własności, zmiany w strukturze i funkcjonowaniu najwyższych organów władzy. Po trzech latach intensywnej pracy (od września 1994 do stycznia 1997 r.) komisja konstytucyjna uchwaliła jeden z siedmiu zaproponowanych projektów nowej Konstytucji Polski. 2 kwietnia 1997 roku Zgromadzenie Narodowe zaakceptowało nową Konstytucję Rzeczypospolitej Polskiej, która została uchwalona w narodowym konstytucyjnym referendum 25 października 1997 roku $^{81}$.

Przyszłość Ukrainy związana jest z zachodnią cywilizacja, nawet pomimo niezrozumienia tego przez znaczną część członków Parlamentu i pomimo niewiary w to dużej części społeczeństwa ukraińskiego. O prozachodniej orientacji Ukrainy świadczą słowa Prezydenta Ukrainy Wiktora Juszczenko, który udzielił 26 marca wywiadu kilku zachodnim mediom - brytyjskiej gazecie „The Financial Times”, francuskiej „Le Monde” i włoskiej „Corriere della Sera” oraz niemieckiej telewizji ZDF, w którym mówił o dążeniu Ukrainy do zacieśniania współpracy z NATO. Zapewnił kolejny raz, że przyłączenie jego kraju do Planu Działania na rzecz Członkostwa w NATO (MAP) nie stanowi zagrożenia dla żadnego sąsiada Ukrainy, w tym dla Rosji. Oświadczył, że dążenie do członkostwa w Sojuszu oznacza dla Ukrainy zapewnienie sobie suwerenności i udziału w najbardziej skutecznym systemie bezpieczeństwa zbiorowego na świecie oraz wolę dzielenia ze wszystkimi europejczykami odpowiedzialności za bezpieczeństwo kontynentu. Wyraził przekonanie, że w ciągu 2 lat poparcie dla integracji z NATO wzrośnie na Ukrainie do 60-70\%. Wyraził nadzieję, że europejscy politycy poprą w Bukareszcie starania Ukrainy o $\mathrm{MAP}^{82}$.

Obiektywna obecność historycznego imperatywu stała się oczywista w samym akcie uchwalonej Konstytucji, jej typie i standardach, zgodnych z zachodnią cywilizacją ${ }^{83}$. Zakulisowe intrygi i zakulisowa dyplomacja, które zdominowały legitymizację Konstytucji i zmiany w niej dokonywane, tylko świadczą o tym, że w pewnych umowach historyczna konieczność może torować sobie drogę w bardzo niespodziewany i nieatrakcyjny sposób. Miejmy nadzieję, że rezultat końcowy usprawiedliwi niedostatki samego procesu.

81 Przebieg prac nad nową Konstytucją RP, 20.03.2008 r., http://kronika.sejm.gov.pl/kronika.97/text/konst/ko1-162.htm.

82 2008.03.27, Interfax-Ukraina, www.unian.net, www.for-ua.com.

83 I. Pasko, Hromadjanske suspilstwo i nacionalna ideja, Ukrajina na tli jewropejskich procesiw. Komparatywni zapisi, Donieck 1999, www.vesna.org.ua/txt/paskoi/grn/11.html. 


\section{Zalącznik nr 1}

\section{Uproszczony schemat procesu ustawodawczego ${ }^{84}$}

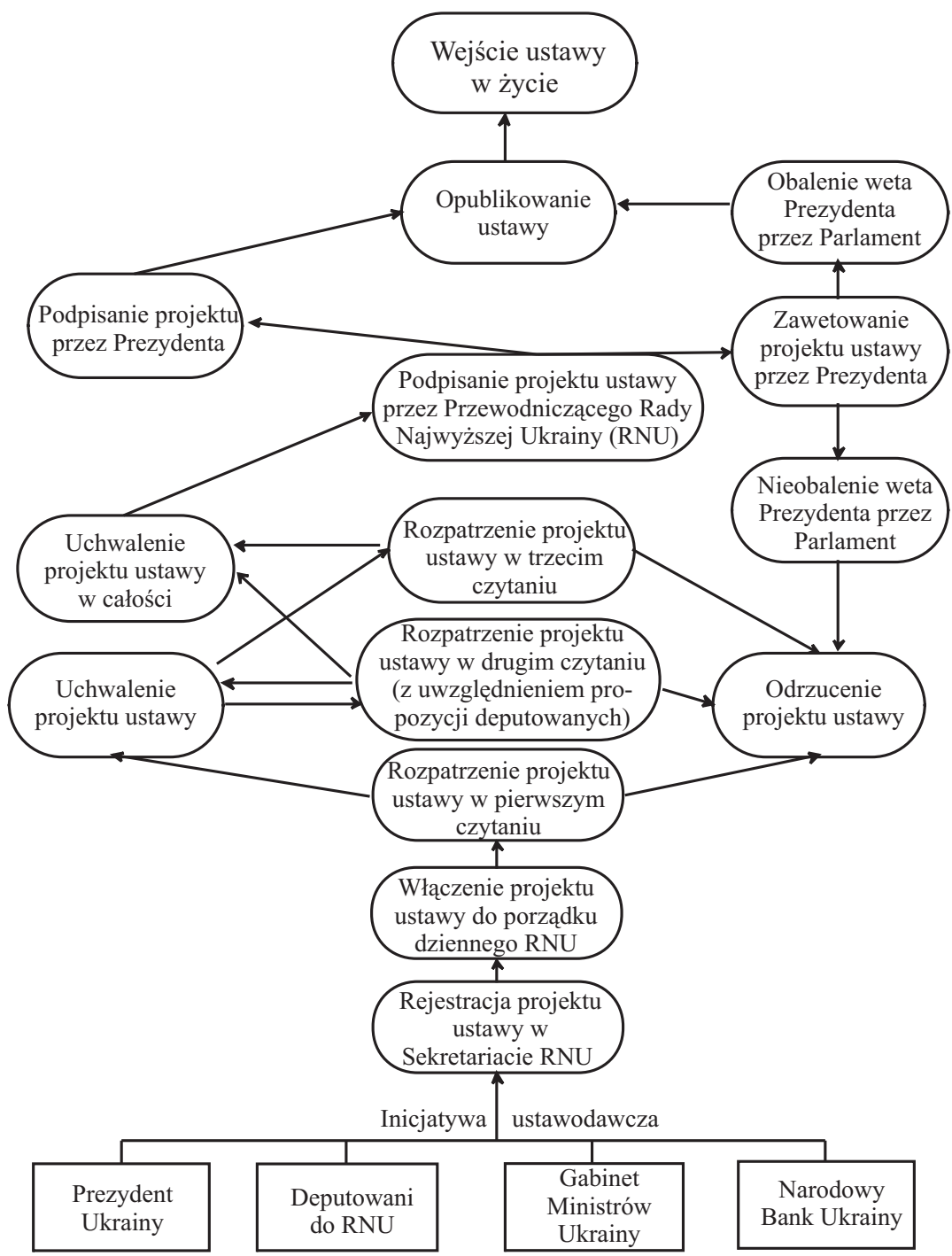

${ }^{84}$ Na podstawie: W. Zamnius, D. Kowrirzenko, D. Kotliar i in., Orientiri Wiborcja 2002, Kijiw 2002, schema 2. Sproszczena schema zakonodawczogo procesu, s. 13. 
Załącznik nr 2

\section{Udział wspólnot lokalnych w formulowaniu przedstawicielskich organów lokalnego samorządu, rad rajonów, wyborów wiejskich, osiedlowych i miejskich jednoosobowych organów władzy ${ }^{85}$}

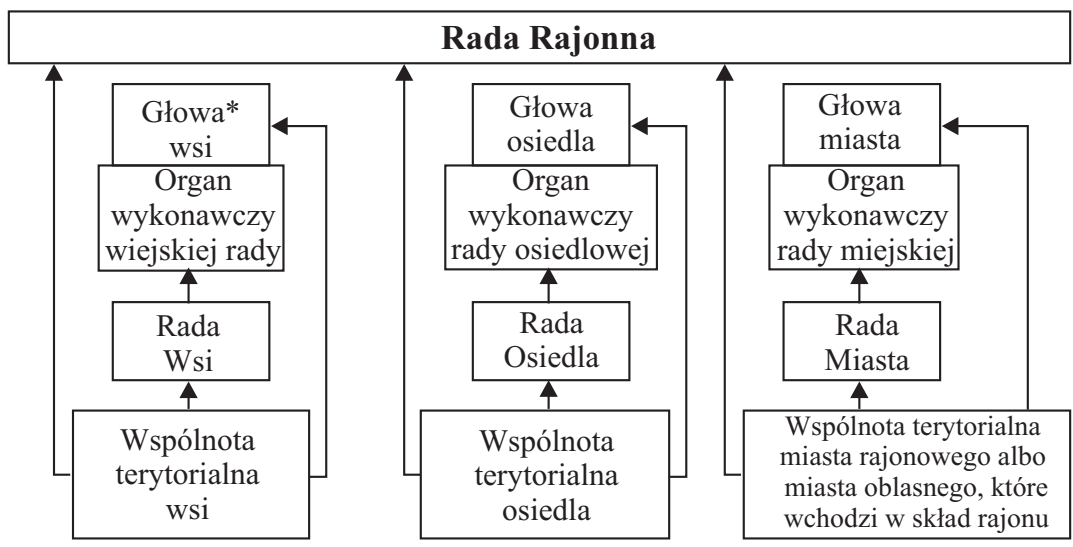

Załącznik nr 3

\section{Sposób formułowania Oblasnej Rady ${ }^{86}$}

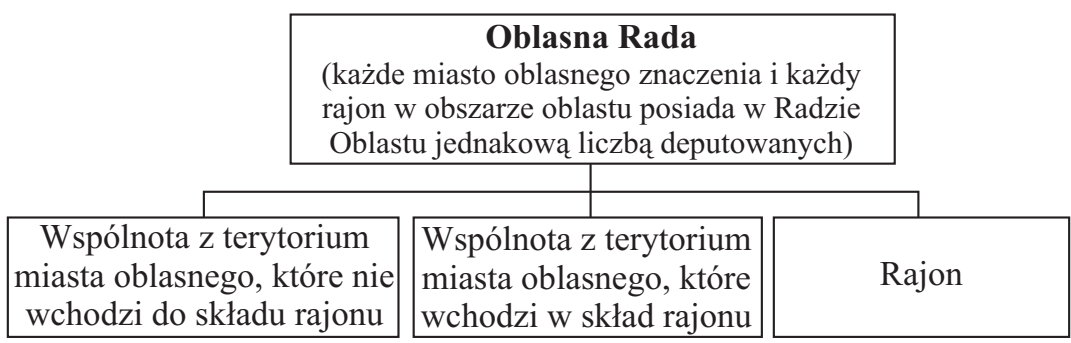

85 Ukraina dzieli się na 24 obwody (województwa, ukr. oblasti), 2 miasta wydzielone (Kijów i Sewastopol) oraz Autonomiczną Republikę Krym, posiadającą własną konstytucję, legislatywę i rząd w ramach ww. jednostek administracyjnych jest 490 rajonow (powiatów) i 488 miast oraz ok. 10 tys. silrad (gromad i osiedli). Wielkie miasta dzielą się na dzielnice, zwane rejonami.

* Głowa, ukr. Голова, to słowo używane jest na określenie wszystkich przedstawicieli władzy, zarówno państwowej, jak i samorządowej, a także szefów przedsiębiorstw i kierowników.

86 W. Zamnius, D. Kowriżenko, op. cit., s. 174. 


\section{Bibliografia}

Albin B. J., Baluk W. (red.), Europa Wschodnia - dekada transformacji - Ukraina, Wrocław 2002.

Dębski S. (red.), „Biuletyn Polskiego Instytutu Spraw Międzynarodowych”, nr 93 (338), 22 grudnia 2005.

Encyklopedia Ukrainoznawstwa, pod red. W. Kubijowicza, t. 1, Kijiw 1993, t. 7, Lwiw 1998, t. 8, Lwiw 2000.

Jakowenko N., Historia Ukrainy do końca XVIII wieku, Lublin 2000.

Konstutycijna reforma $w$ Ukrajini: perebig, stan i percpektiwi: Analit. dop. Centru O. Razumkowa, „Nacjonalna bezpieka i oborona” 2007, nr 1.

Kudriaczenko A. I. (red.), Politiczna sistema i gromadianskie suspilstwo: Ewropejski i Ukrajinski realii (System polityczny i społeczeństwo obywatelskie: Europejskie i Ukraińskie realia), Kijiw 2007.

Łytwyn W., Polityczna arena Ukrainy. Dijowi osoby ta wykonawci, Kijiw 1994.

Łytwyn W. M., Ukraina na meżi tisjaczolit, t. 14 (lata 1991-2000), Kijiw 2000.

Madera A. J., Między Rosja a Europq. Ukraina na rozdrożu, Rzeszów 2000.

„Nowa Ukraina. Zeszyty historyczno-politologiczne” 2006, nr 1, Kraków 2006.

Pasko I., Hromadjanske suspilstwo i nacionalna ideja, Ukrajina na tli jewropejskich procesiw. Komparatywni zapisi, Donieck 1999.

Ukraina: rikz nowoju Konstitucieju: Analit. dop. Centru O. Razumkowa, Kijiw 1997.

Wibori. Do i pislja (chronologija, peredwiborni programi, wislowljuwannja L. D. Kuczmy), Kijiw 2000.

Zamnius W., Kowrirzenko D., Kotliar D. i in., Orientiri Wiborcja 2002, Kijiw 2002.

\section{Wykaz cytowanych aktów prawnych:}

Widomosti Wierchownoji Radi (WWR): numery: 45 z1989, 31 z 1990, 26 z 1991, 33 z 1991, 46 z 1991, 20 z 1992, 46 z 1994, 18 z 1995, 30 z 1996.

„Hołos Ukrainy” z 25.09.1997

Zakon URSR pro zminy ta dopownennja Konstytucji URSR z 27.10.1989 r.

Deklaracija pro dierżawnyj suwernitet Ukrajiny - Wierchowa Rada URSR: Deklaracija z 16.07.1990, nr 55-XII.

Zakon pro zminu i dopownennia do Konstytucji (Osnownoho Zakonu) Ukrajinskoji RSR z 21.05.1991 r.

Zakon pro zminu i dopownennia do Konstytucji (Osnownoho Zakonu) Ukrajinskoji RSR z 5.07.1991 r.

Zakon pro prawonastupnictwo Ukrajiny: z 12.09.1991, nr 1543-XII.

Zakon pro zminu i dopownennia do Konstytuciji (Osnownoho Zakonu) Ukrajinskoji RSR z 14.02.1992 r. 
Pro sklad komisiji z opracjuwannja nowoji Konstutyciji Ukrajiny: Postanowi Werchownoji Radi Ukrajiny z 10.11.1994, nr 231/94-B.

Konstitucijnij dogowir wid 08.06.1995, Nr 1k/95-BP//.

Pro probiedennja wceukrajinskoho referendum z pitannja prijnjattjajanowoji Konstituciji Ukrajini: Ukaz Prezidenta z 26.06.1996, Nr 467/96 (Ukazwtratiw czinnict na podstawi Ukazu Prezidenta Nr 489/96 wid 1.07.96).

Konstitucija Ukrajiny: Zakon z 28.06.1996, Nr 254 k/96-BP//.

Zakon pro wybory narodnych deputatiw Ukrainy z 24.09.1997 r.,

Pro progoloszennja wsenarodnoho referendum za narodnoju iniciatywoju: Ukaz Prezydenta Ukrajiny Nr 65 z 15 stycznia 2000 r.

Zakon pro wnesennja zmin do Konstytuciji Ukrajiny za rezultatami wseukrajinskoho referendum za narodnoju iniciatiwiju: Projekt Zakonu nr 5300 z 25.04.2000 r.

Pro pidgotowku projektu Koncepciji reformuwannja politicznoji systemy Ukrajiny: Rozporjadżennja Prezydenta Ukrajiny Nr 73 z 27 września 2001 r.

Pro wnutriszczie i zownisznie stanowysze Ukrajiny w 2002 roci: Poslannja Prezydenta Ukrajiny do Werchownoji Rady Ukrajiny. Zwernennja wid 15.04.2003, nr 10.

Postanowi Werchownoji Rady Ukrajiny Nr 381-IV z 26.12.2006 r.

\section{Czasopisma:}

„Kamuflaż” 2006, nr 5.

„Kyewskye wedomosti”, 2.07.1997.

\section{Zasoby internetowe:}

http://zakon1.rada.gov.ua.

www.unian.net.

www.for-ua.com.

http://www.pravda.com.ua.

http://kronika.sejm.gov.pl/kronika.97/text/konst/ko1-162.htm.

www.vesna.org.ua/txt/paskoi/grn/11.html.

\section{Summary}

This paper attempts to describe the constitution process in Ukraine from 1990 to 2006, given the dispute between the President and the Highest Council (Parliament). The transformations of post-soviet republics that followed the collapse of the USSR created a need for new political, social and economic agreements to be drawn up to befit the new times. The reforming process of these realms of Ukrainian society's activity was reflected in the evolution of Ukrainian constitutional principles. 
The Ukrainian Constitution determines the political and administrative system of the state. The amendments proposed have favored either the President or the Highest Council, depending on the political situation in the country. Despite numerous attempts, the most important reforms of the system have still not been implemented in Ukraine, which is hardly conducive to the state's stability. The emergence of the foundation for the political system of the independent Ukrainian state is a good illustration of how individual interests of different political forces exert a negative impact on the shaping of a civic society and local self-government, based on transparent principles. 
